
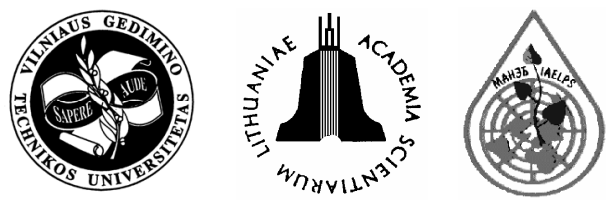

\title{
DEVELOPMENT OF A GFP-BASED BIOSENSOR FOR DETECTING THE BIOAVAILABILITY AND BIODEGRADATION OF POLYCHLORINATED BIPHENYLS (PCBs)
}

\author{
Xuemei Liu, Kieran J. Germaine, David Ryan and David N. Dowling* \\ Dept of Science and Health, Institute of Technology Carlow, Kilkenny Road, Carlow, Ireland \\ *Institute of Technology Carlow, Kilkenny Rd., Carlow, Rep. Ireland \\ E-mail: David.Dowling@ITCARLOW.IE
}

Submitted 14 May 2007; accepted 18 June 2007

\begin{abstract}
Two whole-cell biosensors were constructed to detect the in situ biodegradation of polychlorinated biphenyl by chromosomal insertion of a mini-Tn5-Km $-\mathrm{Pm}:: \mathrm{gfp}[\mathrm{mut} 3]-\mathrm{T}^{0}-\mathrm{T}^{1}$ construct into $P$. fluorescens. In vitro tests showed that the expression of the Pm promoter depended on the growth phase of the biosensors and the concentration of chemical inducers; chlorinated benzoic acid derivatives. A linear relationship between the fluorescent intensity and the $\log _{10}$ concentration of the inducer was observed. One biosensor (F113L::1180gfp) had the ability to degrade PCBs to relevant chlorobenzoic acid derivatives and to induce expression of Gfp. The second biosensor (F113gfp), which cannot degrade PCBs, shows fluorescence after induction by chloro-benzoic acid derivatives. By using these two biosensors, PCB degradation could be detected in vitro and in soil.
\end{abstract}

Keywords: biosensor, Pseudomonas fluorescens F113, PCBs, rhizosphere, root colonisation.

\section{Introduction}

Polychlorinated biphenyls (PCBs) are a group of chlorinated aromatic compounds, which are among the most widely identified environmental contaminants persisting in the biosphere [1].

Reporter genes are widely used as genetic tools for quantification and detection of specific cell populations, gene expression and root colonisation in complex samples [2-4]. Common reporter genes include bacterial bioluminescence (lux) genes, the colorimetric $\beta$-galactosidase (lacZ) gene and genes coding for green fluorescent proteins (GFPs) from the jelly fish Aquoria victoria. The GFPs have been successfully used as reporters within bacterial and yeast hosts due to the ease of in situ detection and the minimal metabolic cost to the host cells [56]. Novel areas for applying these reporter genes have been documented and include their use in constructing whole-cell biosensors as specific and sensitive sensing devices for measuring biologically relevant concentrations of pollutants [7-9]. These biosensors rely on analysis of gene expression, typically by creating transcriptional fusions between a promoter of interest and the reporter gene. The extent of reporter gene expression serves as a measure of the availability of specific pollutants in complex environments. Biosensors developed using this strategy have been reported for monitoring of benzene, toluene, ethylbenzene, and/or xylene using todluxCDABE whole-cell reporter in the contaminated sample [10].
The well-characterised biocontrol strain Pseudomonas fluorescens F113, which was originally isolated from the rhizosphere of sugar beet [11], is an excellent root coloniser and was chosen for gene modification for the degradation of PCBs. The genes responsible for PCB degradation, termed the bph operon from Burkholderia xenovorans LB400 [12], were modified by the cloning of a strongly inducible constitutive (nod box) promoter from Sinorhizobium meliloti upstream of the bph operon in the plasmid pDDPCB and subsequent chromosomal integration into P. fluorescens F113riflacZY, creating P. fluorescens F113L::1180 [13]. This strain was superior to $P$. fluorescens F113rifpcb [14], originally created by the insertion of the bph operon into F113, for the growth on biphenyl and for the biodegradation of PCBs [13].

A number of $g f p$-based $P$. fluorescens F113 biosensors were previously constructed by using fusions of the Escherichia coli rrnBP1 ribosomal promoter and $g f p$ genes. These biosensors were able to monitor the singlecell localization and activity of $P$. fluorescens F113 colonizing alfalfa roots. The monitoring systems permitted non-destructive in situ detection of cells on the entire root system grown in both the presence and absence of 3chlorobiphenyl [15].

In this study, two whole-cell biosensors were constructed by the chromosomal insertion of a promoterreporter construct, xylSPm::gfpmut3 [2] into $P$. fluorescens F113rif and $P$. fluorescens F113L::1180 to create $P$. fluorescens F113gfp and P. fluorescens F113L::1180gfp, respectively. The Pm promoter in this construct is derived 


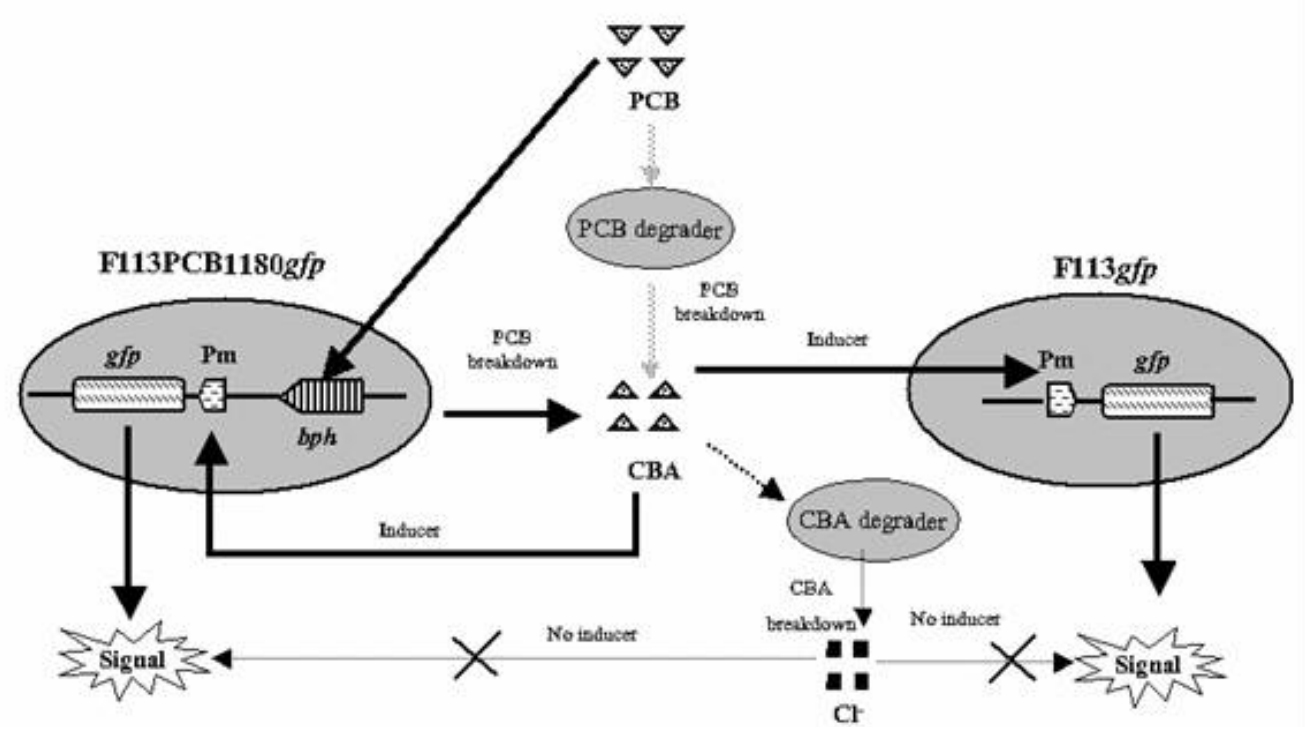

Fig 1. The conceptual basis of the biosensors. Biosensor F113PCB1180gfp is able to report the biodegradation of PCBs by switching on the signal in response to end products of PCB degradation. The second biosensor F113gfp serves as a control and only responds to external chlorobenzoic acids (CBAs)

from the TOL plasmid and regulates the meta-pathway of aromatic hydrocarbon degradation. The meta-pathway is induced by chloro-benzoic acid derivatives and this induction is mediated by the substrate-activated XylS protein. By combining these two biosensors, PCB degradation can be detected in situ (Fig 1). The initial characterisation of these biosensors is described in this report.

\section{Materials and methods}

\subsection{Bacterial culture conditions}

Bacterial strains were cultivated at $30^{\circ} \mathrm{C}$ on LuriaBertani (LB) medium, Pseudomonas minimal medium (MM) [14] supplemented with $10 \mathrm{mM}$ sodium citrate or Pseudomonas minimal medium amended with $10 \mathrm{mM}$ crystal biphenyl. The Escherichia coli strains were grown at $37{ }^{\circ} \mathrm{C}$ with constant shaking in LB medium. Antibiotics were routinely added at the following concentrations: kanamycin (Kan) $50 \mu \mathrm{g} \mathrm{ml}^{-1}$ and rifampicin (Rif) $50 \mu \mathrm{g} \mathrm{ml}^{-1}$.

To detect the activity of the biosensors in vitro, $100 \mathrm{ml}$ of MM supplemented and $1 \mathrm{mM}$ chemical inducers were placed into $500 \mathrm{ml}$ flasks. These flasks were inoculated with $1 \times 10^{8}$ bacterial cells. Soil experiments were set up by inoculating $1 \times 10^{8}$ free cells per gram soil.

\subsection{Construction and characterisation of Gfp biosensor strains}

The pJBA26 [2] plasmid carrying the mini-Tn5 $-\mathrm{km}^{\mathrm{r}}-$ Pm::gfpmut3- $\mathrm{T}_{0}-\mathrm{T}_{1}$ transposon was introduced into $P$. fluorescens F113 derivatives by triparental matings, as described previously [16]. The selection plates were LB supplemented with Rif and Kan. After mating, the transconjugant colonies were purified and tested by spraying with 2, 3-dihydroxybiphenyl to detect the presence of an active $b p h C$ gene product, thereby confirming the presence of the $b p h$ operon [14].
The insertion of the gfp gene was confirmed by PCR using primers Pgfp(up) 5'-GGTCTAGATGTGTGAAA TTGTTATCCG-3' and Pgfp(down) 5'-CTCTCAAGC TTATTTGTATAGTTCATCCATGC -3' [17]. PCR amplification experiments were performed in a Hybaid PCR Machine (Hybaid Limited). $50 \mu \mathrm{l}$ reaction mixtures contained $50 \mathrm{ng}$ DNA, $5.0 \mu \mathrm{M}$ of each primer, $200 \mu \mathrm{M}$ dNTPs, $3.0 \mu 11.5 \mu \mathrm{M} \mathrm{MgCl}_{2}, 5.0 \mu 110 \times$ reaction buffer and $0.625 \mathrm{U}$ of Taq Polymerase (All reagents supplied by Promega, Madison, Wis). After an initial denaturation for 2 min at $95^{\circ} \mathrm{C}$, a total of 35 cycles were performed using the following program: $95{ }^{\circ} \mathrm{C}$ for $30 \mathrm{sec}$, annealing at $56{ }^{\circ} \mathrm{C}$ for $1 \mathrm{~min}$, extension at $72{ }^{\circ} \mathrm{C}$ for $1 \mathrm{~min}$, with a final termination step of one cycle of $7 \mathrm{~min}$ at $72{ }^{\circ} \mathrm{C}$.

Southern blotting analysis was carried out to detect the chromosomal insertion of the $g f p$ gene and the location of the insertion. Undigested and HindIII-digested genomic DNA from F113rif, F113gfp, F113L::1180, F113L::1180gfp and pJBA26 were run on a $1 \%(w / v)$ agarose gel. The DNA was blotted by capillary transfer onto a nylon membrane (Boehringer Mannheim). The $g f p$ DNA probe for Southern hybridisations was prepared by the incorporation of DIG-11-dUTP (Boehringer Mannheim) during PCR using $\mathrm{P}_{\mathrm{gfp}(\mathrm{up})}$ and $\mathrm{P}_{\mathrm{gfp}(\mathrm{down})}$ primers and plasmid DNA of pJBA26 as a template. The DIG-bphC probe was made during PCR using bphC LCC forward and reverse primers [18] and genomic DNA of F113L::1180 as a template. Hybridisation using the DIGgfp probe was performed at $42{ }^{\circ} \mathrm{C}$ overnight in hybridisation buffer (Roche). The membrane was incubated for $1 \mathrm{~h}$ with 1: 5000 dilution of alkaline phosphatase-conjugated anti-digoxigenin antibody. Colorimetric detection of digoxigenin-labelled DNA fragments was carried out using NBT/BCIP (Roche) as the substrate for alkaline phosphatase. The membrane was inoculated for $16 \mathrm{~h}$ and photographed. To perform re-probing experiments, the membrane was washed using formamide for $1 \mathrm{~h}$ and re- 
probed with a DIG-bphC probe following the same procedure. Restriction analysis was carried out based on the mini-Tn5-km ${ }^{\mathrm{r}}-\mathrm{Pm}:$ :gfpmut $3-\mathrm{T}_{0}-\mathrm{T}_{1}$ transposon and $b p h$ operon.

The growth rate in LB, SA broth [19], MM plus succinate $(10 \mathrm{mM})$ and $\mathrm{MM}$ plus sodium citrate of F113L::1180gfp and F113gfp and growth rate in MM plus biphenyl of F113L::1180gfp were tested and compared to their parental strains. Their ability to utilise various carbon sources was tested by comparing the transconjugants to their parental strains using the gramnegative Biolog ${ }^{\circledR}$ NT plates to ensure that the $g f p$ transposon had not randomly inserted into genes involved in the major catabolic pathways of the strains.

\subsection{Epifluorescent microscopy and spectrofluoremetry}

The biosensor cells from liquid cultures were visualised using a Nikon E400 epifluorescent microscope equipped with a $100 \mathrm{~W}$ mercury short arc photo-optic lamp and two filters with the excitation wavelength of 465-495 nm and 450-490 nm, respectively. Lucia ${ }^{\circledR}$ imaging software (version 4.6) was used to capture and process microscopic images. Fluorescent intensity from biosensor cells was measured as described previously [20] with a Hitachi fluorescent spectrophotometer Model F-2000 set at an excitation wavelength of $475 \mathrm{~nm}$ and emission detection at $511 \mathrm{~nm}$. Relative fluorescence unit (RFU) was defined as the culture fluorescence intensity relative to culture biomass at $\mathrm{OD}_{600 \mathrm{~nm}}$ (measured using a Hitachi U-2001 Spectrophotometer).

\subsection{Induction experiments}

Growth phase-dependent and exposure timedependent $g f p$ expression in the biosensors was tested by growing both of the biosensors in $\mathrm{MM}+10 \mathrm{mM}$ sodium citrate broth with different concentrations of 3-CBA. The $\mathrm{OD}_{600 \mathrm{~nm}}$ values and fluorescent intensity were measured at $2 \mathrm{~h}$ intervals over a $24 \mathrm{~h}$ period. Dose-dependent experiments were carried out by centrifuging $2 \mathrm{ml}$ of stationary phase biosensor cells which were grown in MM supplemented with $10 \mathrm{mM}$ sodium citrate, for $5 \mathrm{~min}$. at 3,000 $\times \mathrm{g}$, and mixing with $2 \mathrm{ml}$ of benzoate derivative compounds to final concentrations ranging from $0.1 \mathrm{ppm}$ to $1000 \mathrm{ppm}$ and inoculated at room temperature (RT) for $6 \mathrm{~h}$. Single fluorescent cells were examined by epifluorescent microscope.

\subsection{Biosensor activity in vitro}

Biosensor strains to detect PCB degradation: F113L:: $1180 \mathrm{gfp}$ was inoculated into $\mathrm{MM}+10 \mathrm{mM}$ sodium citrate supplemented with $1 \mathrm{mM}$ 3-CBP, 2, 3-dichloribiphenyl (2,3-DiCBP) or 3,5-dichloribiphenyl (3,5-DiCBP) liquid media for $5 \mathrm{~d}$. RFU was measured after the culture grew to stationary phase; F113L::1180gfp was also inoculated in $1 \mathrm{mM} 3$-CBP spiked soil at room temperature for $10 \mathrm{~d}$. Strain F113gfp was inoculated as control in both liquid and soil experiments.
To count the percentage of $g f p$ fluorescent cells by epifluorescent microscopy, two methods were employed. The first method involved visualising the total number of cells under white light and examining the green fluorescent cells under the UV light with the filter excitation of $450-490 \mathrm{~nm}$. The percentage of the fluorescent cells was the ratio of fluorescent cells to the number of total cells. The second method involved staining the cells using $0.1 \%$ acridine orange and visualising the image by epifluorescent microscope with two ranges of excitation filters, 465-495 nm (for visualising the gfp fluorescent cells) and 450-490 $\mathrm{nm}$ (for visualising total cells), and the percentage of fluorescent cells was calculated as the ratio of green fluorescent cells to the number of total cells (green and red).

\subsection{Statistical analysis}

All experiments were performed using several replicates. The results shown are the averages of triplicate sampling for error analysis. Standard deviations are shown as error bars within the graphs at the $\mathrm{P}<0.05$ level of significance.

\section{Results and Discussion}

\subsection{Construction of two biosensors responding to PCBs and CBAs}

$\mathrm{Km}^{\mathrm{r}}$ and Rif $^{\mathrm{r}}$ transconjugants were obtained after $4 \mathrm{~d}$ on selective plates by mating the donor E.coli pJBA26 and recipient $P$. fluorescens F113rif or F113L::1180 with the helper plasmid pRK600. The transconjugants were purified by restreaking three times on selective plates. One transconjugant from each conjugation that visually exhibited green fluorescence by epifluorescent microscope was selected and designated $P$. fluorescens F113gfp and F113L::1180gfp, respectively. The presence of the $g f p$ gene was also confirmed by PCR analysis resulting in a 742bp gfp specific amplicon (Fig 2).

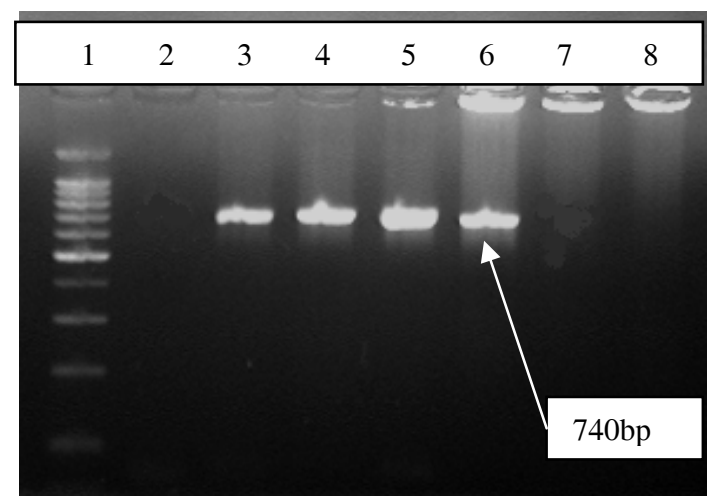

Fig 2. PCR amplification of 740bp gfp gene in donor and transconjugant strains. 1 - 100bp size ladder, 2 - F113rif, 3 - F113gfp, 4 - pJBA26, 5 - F113pcbL1180gfp, 6 F113pcbL1180gfp, 7 - F113pcbL1180, 8 - water control

Amplification was not detected in recipient bacteria. Southern blotting showed that the DIG- $g f p$ probe hybridised with the HindIII digested and undigested genomic 
DNA of the two $g f p$-transformed strains, whereas not with the digested or undigested genomic DNA from the parental strains (Fig 3A). In addition, re-probing with DIG- $b p h C$ showed that the $b p h C$ probe hybridised with the digested and undigested genomic DNA of F113L::1180gfp and its parental strains giving the same size product bands (Fig 3B).

\section{0}

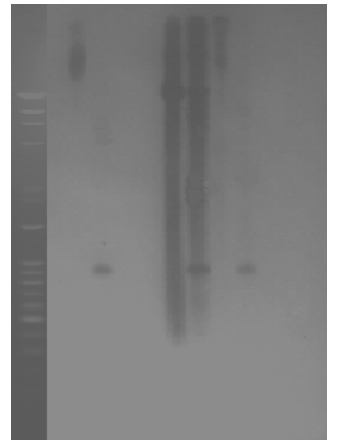

A

Fig 3. Southern blotting of undigested and HindIIIdigested genomic DNA probed with: (A) DIG-gfp; (B) DIG-bphC. 0 - 100bp ladder and $\lambda$ HindIII DNA marker; 1 - undigested genomic DNA of F113PCB1180gfp; 2 HindIII digested genomic DNA of F113PCB1180gfp; 3 undigested genomic DNA of F113PCB1180; 4 - HindIII digested genomic DNA of F113PCB1180; 5 - undigested pJBA26; 6 - HindIII digested pJBA26; 7 - undigested genomic DNA of F113gfp; 8 - HindIII digested genomic DNA of F113gfp; 9 - undigested genomic DNA of F113rif; 10 - HindIII digested genomic DNA of F113gfp

BphC enzyme activity in F113L::1180gfp was confirmed by spraying 2, 3- dihydroxybiphenyl on the colonies, which showed the yellow colour of the meta cleavage product, 2-hydroxy-6-oxo-6-phenylhexa- 2,4-dienoic acid.
Generation time of the transconjugants were similar to their parental strain on a range of substrates. In addition, the metabolic activity of the $g f p$ transconjugants was examined by comparison with their parental strains using Biolog ${ }^{\circledR}$ GN. There was no change in the substrate utilization patterns, indicating that the insertion of the $g f p$ construct did not affect essential genes involved in the metabolic pathways of the strains (data not shown).

\subsection{Growth phase dependence of $g f p$ expression in the biosensors}

When grown on citrate, with the inducer 3-CBA in concentrations of $0 \mathrm{mM}$ to $0.1 \mathrm{mM}$, F113L::1180gfp cultures exhibited a lag phase of around $4 \mathrm{~h}$ and then entered the exponential growth phase. Lag phase and exponential phase were found to increase with the increasing concentration of 3-CBA from $1 \mathrm{mM}$ to $2 \mathrm{mM}$ (Fig 4A). The GFP expression was linked to growth dynamics, with the net fluorescence of the culture increasing during the exponential phase of growth. The induction of the $g f p$ expression started after $6 \mathrm{~h}$ and the final fluorescence intensity reached a maximum at the end of exponential growth, and was stable in the stationary phase after $14 \mathrm{~h}$ (Fig 4B).

\subsection{Biosensors respond to chlorobenzoate derivatives in a concentration-dependent manner}

Biosensors in stationary phase exposed to inducer 3-CBA, provided a consistent fluorescence value after an incubation time of $6 \mathrm{~h}$. The specificity and sensitivity of both of the biosensors were then tested using various chloro-benzoate derivatives and a stationary phase culture. A linear plot of the fluorescent intensity versus $\log _{10}$ 3-CBA, 2,3-dichlorobenzoate (2,3-DiCBA) and 3,5-dichlorobenzoate (3,5-DiCBA) concentration was derived from data collected after $6 \mathrm{~h}$ incubation over the range of 4-400 ppm (Fig 5).

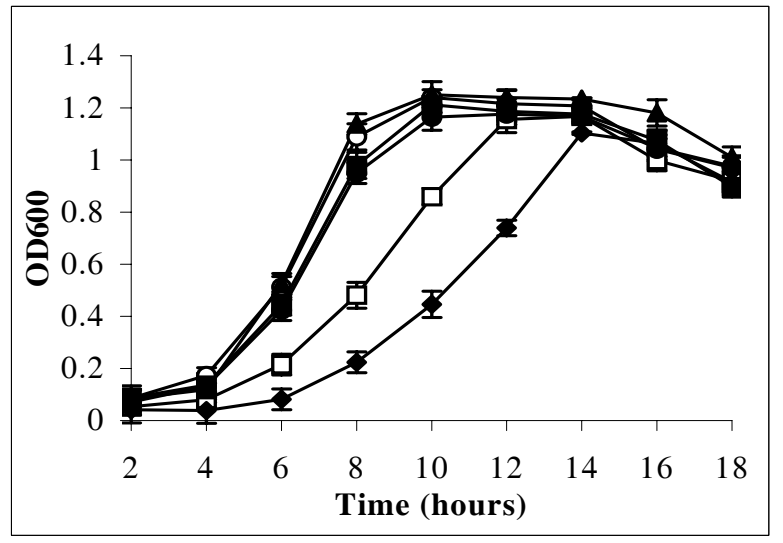

A

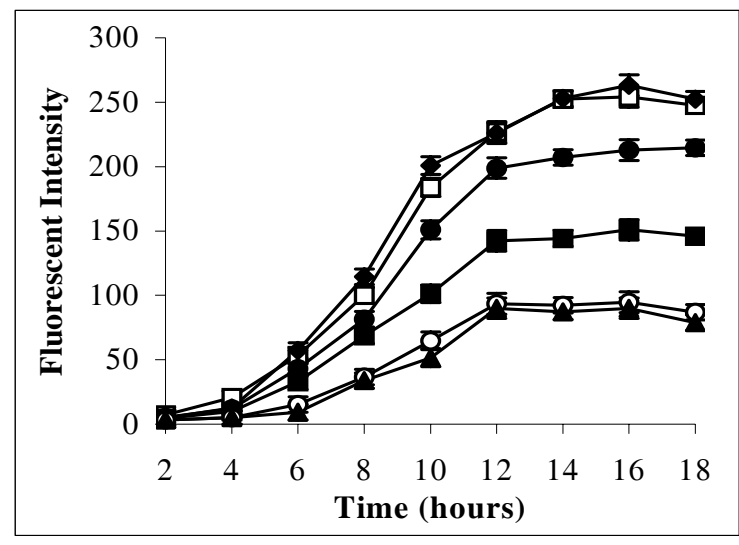

B

Fig 4. Response of the biosensor to different concentrations of 3-chlorobenzoic acid (3-CBA). Mean $\mathrm{OD}_{600 \mathrm{~nm}}(\mathrm{~A})$ and fluorescence intensity (B) versus time of F113L::1180gfp cultures grown in sodium citrate as sole carbon source with varying concentrations of 3-CBA. 0mM (closed triangle), $0.001 \mathrm{mM}$ (open circle), $0.01 \mathrm{mM}$ (closed square), $0.1 \mathrm{mM}$ ( closed circle ), $1 \mathrm{mM}$ (open square), $2 \mathrm{mM}$ (closed diamond) 


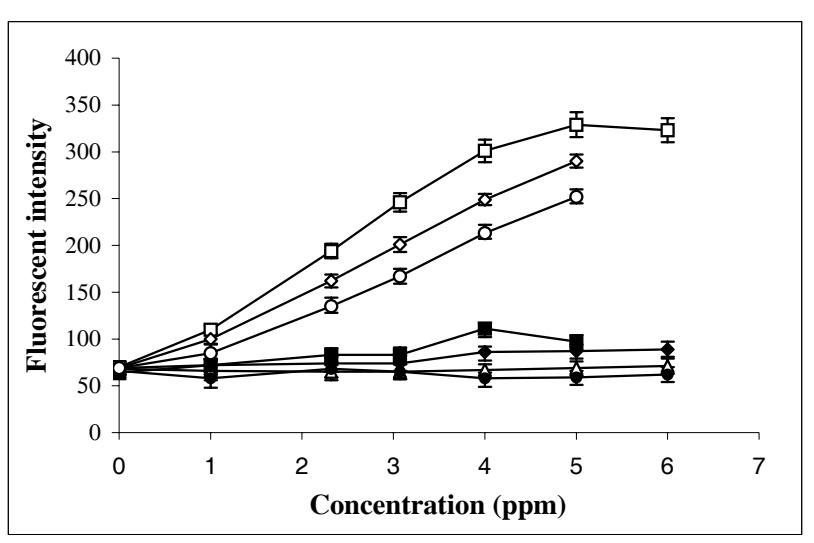

Fig 5. Fluorescence response of biosensor F113L:: 1180Pgfp to various concentrations of chloro-benzoic acid derivatives measured after $6 \mathrm{~h}$ exposure periods. 3-CBA (open square), 2, 3-DiCBA (open diamond), 3, 5-DiCBA (open circle ), 3, 4-DiCBA closed square), Benzoate (closed diamond), 2-CBA open triangle), 4-CBA (closed circle)

Under the same concentration, the induction ability of these chemicals was in the order 3-CBA > 2,3-DiCBA $>3,5$-DiCBA. The biosensor could be induced by 3,4dichlorobenzoate (3,4-DiCBA), but there was no obvious relationship between the fluorescent intensity and concentrations.

In contrast, benzoate, 2-CBA or 4-CBA did not induce the $g f p$ expression examined by spectrofluoremetry. However, less than $5 \%$ of the cells were found fluorescent by epifluorescent microscopy. There were also about $2 \%$ fluorescent cells detected by epifluorescent microscope induced by 3-CBA, 2,3-DiCBA or 3,5-DiCBA at low concentration as $0.1 \mathrm{ppm}$.

It was noted that not all of the cells were fluorescent when the concentration of the inducers were less than $10 \mathrm{ppm}$ as revealed under the epifluorescent microscope. The fluorescent cells must represent over $12 \%$ of the total population so that fluorescence can be detected by fluorimetry. This is in agreement with Bongaerts, et al.,
[21], who stated that a minimum number of bacteria expressing Gfp were required to produce measurable fluorescence by a fluorimeter.

\subsection{Biosensor activity for detecting PCB availability and degradation in vitro}

In liquid culture, the $g f p$ gene was expressed in biosensor F113L::1180gfp when inoculated into 3-CBP, 2,3DiCBP or 3,5-DiCBP as measured by Spectrofluoremetry (Fig 6A and B).

Confirmation using the epifluorescent microscope showed $100 \%$ cell fluorescence; In 3-CBP spiked soil experiments, more than $30 \%$ F113L::1180gfp cells were visualised as $g f p$-expressing cells by epifluorescent microscope when this biosensor was introduced as free cells after $10 \mathrm{~d}$ inoculation. No fluorescent cells were found when F113gfp was inoculated in the same soil. These results showed that $g f p$ expression could not be induced directly by 3-CBP, 2,3-DiCBP or 3,5-DiCBP, but was induced by 3 -CBA or 2,3-DiCBA or 3,5-DiCBA which were the breakdown products of biosensor F113L:: 1180 gfp activity. These results indicated that the biosensor F113L::1180gfp could detect its own ability to degrade PCBs in liquid culture and in soil.

The majority of promoter-reporter biosensor systems reported are constructed by cloning a promoter upstream of the reporter gene cassette and the subsequent transfer of the plasmid construct into specific strains [22-25]. However, loss of these plasmids due to the starvation [26] and reduction in expression of the reporter gene due to multiple copies of the promoter binding region on the plasmid [27] pose problems when these biosensors are applied to real situations. There are few reports of biosensors based on the chromosomal insertion of the promoterreporter gene which produce more stable strains than the plasmid-based biosensors [9-10, 15]. In this study two chromosome-based biosensors $P$. fluorescens F113gfp and $P$. fluorescens F113L::1180gfp were constructed. The insertion of the gfp construct into the chromosome of

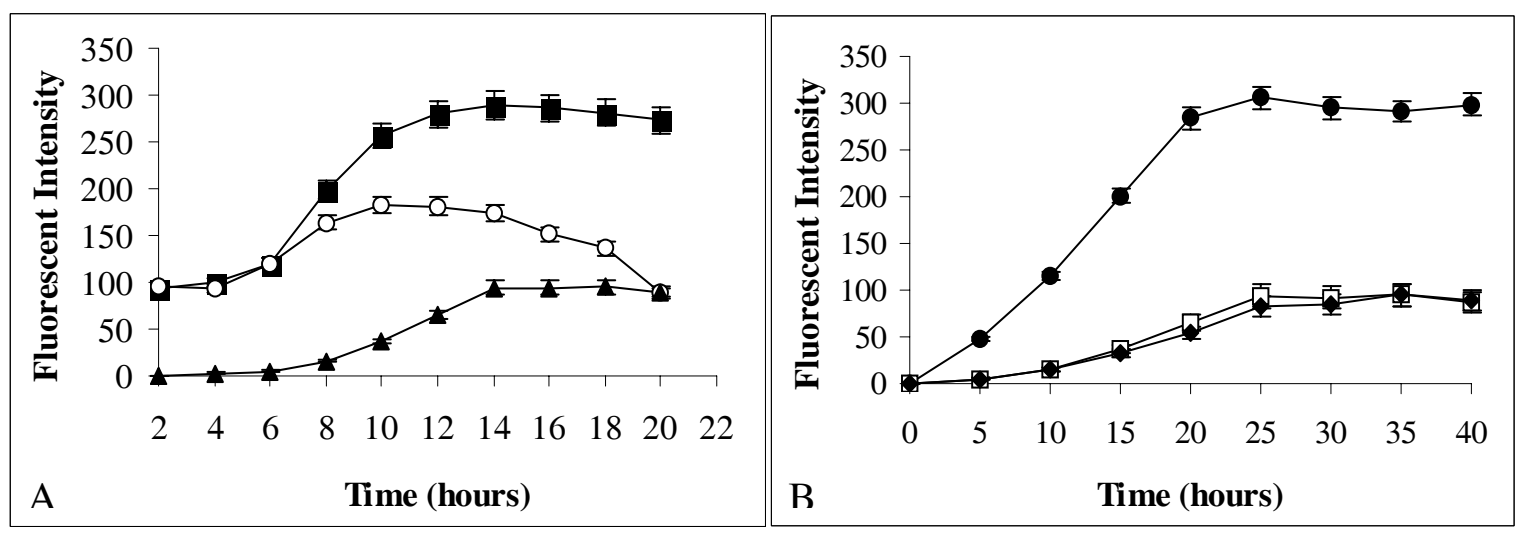

Fig 6. Biosensor F113PCB1180gfp detecting the biodegradation of 3-CBP, 2, 3-DiCBP and 3, 5-DiCBP. (A) detecting the biodegradation of 3-CBA by B13: Co-culture of F113PCB1180gfp and B13 (open circle), pure culture of F113PCB1180gfp (closed square) and pure culture of B13 (closed triangle); (B) detecting the biodegradation of 3-CBP by ITCBP: co-culture ITCBP and F113gfp (closed circle), pure culture of ITCBP (closed diamond) and pure culture of F113gfp (open square) 
the bacteria was confirmed by PCR and Southern blotting. The product from the Southern blotting using DIGgfp probe was $\sim 900 \mathrm{bp}$, due to the fact that there is HindIII restriction site within the mini-Tn5 [28]. Studies have shown that the integration of the $g f p$ reporter gene into the chromosome affected the growth ability of Ralstonia eutropha on 2, 4-dichlorophenoxyacetic acid [29] and on biphenyl [30]. Chromosomal insertion of the $g f p$ construct did not affect any major catabolic pathway of these biosensor strains as measured by Biolog and growth dynamics or plant root colonisation (Fig 7), neither did the insertions disrupt the bph operon as shown by Southern hybridisation experiments. Expression of the Pm promoter is substrate-dependent and host-specific [31]. In the pure culture study, the Pm promoter was induced by 3CBA in both of the biosensor strains and was greatly induced by 2,3-DiCBA, 3,5-DiCBA and slightly induced by 3,4-DiCBA as determined by the spectrofluoremetry and the epifluorescent microscopy. In addition, a linear relationship was observed between the fluorescent intensity and the concentration of 3-CBA, 2,3-DiCBA and 3,5DiCBA ranging from 4 to $400 \mathrm{ppm}$. Previous studies used an immobilized recombinant $E$. coli reporter to detect the bioavailability of 4-chlorobenzoate [32]. Our work indicates that the biosensors have the potential ability to detect the bioavailability of other CBA derivatives, which are produced by the biodegradation of PCBs in the environment.

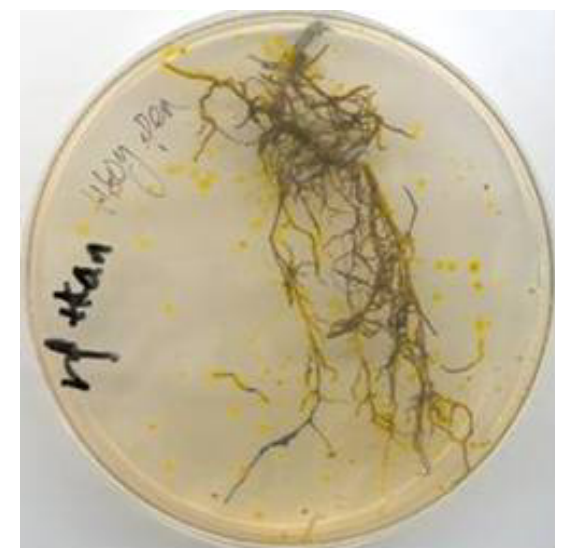

Fig 7. Colonisation of Pea in PCB-contaminated soil microcosms by Biosensor F113L:1180 gfp. The autography plate was sprayed with 2,3-dihydroxy biphenyl following 2 days incubation at $30{ }^{\circ} \mathrm{C}$. The pattern of biosensor colonisation is revealed by the yellow colonies

Previous applications of $g f p$ focused on its use as a biomarker to investigate survival and competition ability of bacterial inoculants [3, 30, 33-35] and as biosensors to detect the bioavailability or toxicity of environmental pollutants $[5,8,7,9,10,22-25]$. In this paper, the biosensor system could detect not only the bioavailability but also the degradation of PCBs. It had been reported that using $P$. fluorescens F113rifpcbgfp to detect the biodegradation of 3-CBP during root colonisation in 3-CBP spiked soil was possible [15]. However, only $1 \%$ of the bacterial cells were shown to be fluorescent. This may be due to the relatively low level of $b p h$ expression in this strain and possibly because the natural occurring 3-CBA degraders removed the 3-CBA so that fluorescence was observed in only a few cells. This hypothesis was confirmed following testing in vitro, when co-inoculated F113L::1180gfp and a 3-CBA degrader Pseudomonas sp. strain B13 [36] in a 3-CBA media, after $20 \mathrm{~h}$ incubating, no fluorescent cells could be observed by epifluorescent microscopy.

The biosensor was shown to colonise pea plants both quantitatively (data not shown) and qualitatively (see Fig 7) in a similar manner to the parent strain $P$. fluorescens F113.

\section{Conclusions}

Two whole cell Pseudomonas biosensor strains were constructed to monitor the bioavailability and biodegradation of PCBs. Such sensor bacteria proved useful in the monitoring of PCB degradation in vitro. However, further studies will be needed to investigate the encapsulation of the biosensor in an alginate matrix and its use to report on PCB degradation in real PCB-contaminated soils.

\section{Acknowledgments}

This work was supported in part by grants from the Higher Education Authority of Ireland (HEA) PRTLI programmes and European Union (EU) contracts BIO4CT-2227, QLK3-CT2000-00164 \& QLK3- CT200100101 and the SFI BRG programme.

\section{References}

1. SAFE, S. H. Polychlorinated biphenyls (PCBs): Environmental impact, biochemical and toxic responses, and implications for risk assessment. Crit. Rev. Toxicol., 1994, 24, p 87-149.

2. MOLLER, S.; STERNBERG, C.; ANDERSEN, J. B.; CHRISTENSEN, B. B.; RAMOS, J. L.; GIVSKOW, M.; MOLIN, S. In situ gene expression in mixed-culture biofilms: evidence of metabolic interactions between community members. App. Environ. Microbiol., 1998, 64, p 721-732.

3. CASSIDY, M. B.; LEUNG, K. T.; LEE, H.; TREVORS, J. T. A comparison of enumeration methods for culturable Pseudomonas fluorescens cells marked with green fluorescent protein. J. Microbiol. Meth., 2000, 40, p 135-145.

4. GERMAINE, K.; KEOGH, E.; GARCIA-CABELLOS, G.; BORREMANS, B.; VAN DER LELIE, D.; BARAC, T.; OEYEN, L.; VANGRONSVELD, J.; PORTEOUS MOORE, F.; MOORE, E. R. B.; CAMPBELL, C. D.; RYAN, D.; DOWLING, D. N. Colonisation of poplar trees by gfp expressing bacterial endophytes. FEMS Microbio. Ecol., 2004, 48, p 109-118.

5. ROBERTO, F.; BARNES, J. and BRUHN, D. Evaluation of a GFP reporter gene construct for environmental arsenic detection. Talanta, 2002, 58, p 181-188.

6. LARRAINZAR, E.; O'GARA, F.; MORRISSEY, J. P. Applications of Autofluorescent Proteins for In Situ Studies in Microbial Ecology. Аnпи Rev Microbiol, 2005, 5(9), p 257-77.

7. WILLARDSON, M. B. B.; WILKINS, F. J.; RAND, A. T.; SCHUPP, M. J.; HILL, K. K.; KEIM, P.; JACKSON, J. P. 
Development and testing of a bacterial biosensor for toluene-based environmental contaminants. Appl. Environ. Microbiol., 1998, 64, p 1006-1012.

8. SCHREITER, P. P.; GILLOR, O.; POST, A.; BELKIN, S.; SCHMID, R. D. and BACHMANN, T. T. Monitoring of phosphorus bioavailability in water by an immobilized luminescent cyanobacterial reporter strain. Biosensors Bioelectro, 2001, 16, p 811-818.

9. TAYLOR, C. J.; BAIN, L. A.; RICHARDSON, D. J.; SPIRO, S. and RUSSELL, D. A. Construction of wholecell gene reporter for the fluorescent bioassay of nitrate. Anal. Biochem., 2004, 328, p 60-66.

10. APPLEGATE, M. B.; KEHRMEYER, R. S.; SAYLER, S. G. A chromosomally based tod-luxCDABE whole-cell reporter for benzene, toluene, ethybenzene, and xylene (BTEX) sensing. Appl. Environ. Microbiol., 1998, 64, p 2730-2735.

11. SHANAHAN, P.; O'SULLIVAN, D. J.; SIMPSON, P.; GLENNON, J. D.; O'GARA, F. Isolation of 2, 4-diacetylphloroglucinol from a fluorescent pseudomonad and investigation of physiological parameters influencing its production. Appl. Environ. Microbiol., 1992, 58, p 353-358.

12. GORIS, J.; DE VOS, P.; CABALLERO-MELLADO, J.; PARK, J.; FALSEN, E.; QUENSEN III, J. F.; TIEDJE, J. M.; VANDAMME, P. Classification of the biphenyl-and polychlorinated biphenyl-degrading strain LB400T and relatives as Burkholderia xenovorans sp. nov. International Journal of Systematic and Evolutionary Microbiology, 2004, 54, p 1677-1681.

13. VILLACIEROS, M.; WHELAN, C.; MACKOVA, M.; MOLGAARD, J.; SÁNCHEZ-CONTRERAS, M.; LLORET, J.; AGUIRRE DE CÁRCER, D.; ORUEZÁBAL, R. I.; BOLAÑOS, L.; MACEK, T.; KARLSON, U.; DOWLING, D. N.; MARTÍN, M.; RIVILLA, R. PCB Rhizoremediation by Pseudomonas fluorescens F113 derivatives using a Sinorhizobium meliloti nod system to drive bph gene expression. Appl. Environ. Microbiol., 2005, 71, p 2687-2694.

14. BRAZIL, G. M.; KENEFICK, L.; CALLANAN, M.; HARO, A.; DE LORENZO, V.; DOWLING, D. N.; O'GARA, F. Construction of a rhizosphere Pseudomonad with potential to degrade polychlorinated biphenyls and detection of bph gene expression in the rhizosphere. Appl. Environ. Microbiol., 1995, 61, p 1946-1952.

15. BOLDT, T. S.; SORENSEN, J.; KARLSON, U.; MOLIN, S.; RAMOS, C. Combined use of different Gfp reporters for monitoring single-cell activity of a genetically modified PCB degrader in the rhizosphere of Alfalfa. FEMS Microbiol. Ecol., 2004, 48, p 139-148.

16. HERRERO, M.; DE LORENZO, V.; TIMMIS, K. N. Transposon vectors containing non-antibiotic resistance selection markers for cloning and stable chromosomal insertion of foreign genes in gram-negative bacteria. J. Bacteriol., 1990, 172, p 6557-6567.

17. ANDERSEN, J. B.; STERNBERG, C.; POULSEN, L. K.; BJØRN, S. P.; GIVSKOV, M.; MOLIN, S. New unstable variants of green fluorescent protein for studies of transient gene expression in bacteria. Appl. Environ. Microbiol., 1998, 64, p 2240-2246.

18. HOGAN, J.; SHERLOCK, O.; RYAN, D.; WHELAN, C.; FRANCESCONI, S.; RIVILLA, R.; DOWLING, D. N. Fluorescence Resonance Energy Transfer (FRET) based molecular detection of a genetically modified PCB degrader in soil. FEMS Microbiol. Lett., 2004, 236, p 349-357.

19. SCHER, F. M.; BAKER, R. Effects of Pseudomonas putida and a synthetic iron chelator on induction of soil suppressiveness to Fusarium wilt pathogens. Phytopathology, 1982, 72, p 1567-1573.

20. RAMOS, C.; MOLBAK, L.; MOLIN, S. Bacterial activity in the rhizosphere analysed at the single-cell level by monitoring ribosome contents and synthesis rates. Appl. Environ. Microbiol., 2000, 66, p 801-809.

21. BONGAERTS, R. J.; HAUTEFORT, I.; SIDEBOTHAM, J. M.; HINTON, J. K. Green fluorescent protein as a marker for conditional gene expression in bacterial cells. $\mathrm{Me}$ thods Enzymo., 2002, 358, p 43-66.

22. LAYTON, A. C.; MUCCINI, M.; GHOSH, M. M.; SAYLER, G. S. Construction of a bioluminescent reporter strain to detect polychlorinated biphenyls. Appl. Environ. Microbiol., 1998, 64, p 5023-5026.

23. STINER, L.; HALVERSON, L. J. Development and characterization of a green fluorescent protein-based bacterial biosensor for bioavailable toluene and related compounds. Appl. Environ. Microbiol., 2002, 68, p 1962-1971.

24. IKENO, S.; OGINO, C.; ITO, T.; SHIMIZU, N. Detection of benzene derivatives by recombinant E. coli with Ps promoter and GFP as a reporter protein. J. Biochem. Eng., 2003, 15, p 193-197.

25. CHANG, S. T.; LEE, H. J.; GU, M. B. Enhancement in the sensitivity of an immobilized cell-based soil biosensor for monitoring PAH toxicity. Sens. Actuators B., 2004, 97, p 272-276.

26. LEFF, G. L.; LEFF, A. A. Use of green fluorescent protein to monitor survival of genetically engineered bacteria in aquatic environments. Appl. Environ. Microbiol., 1996, 62, p 3486-3488.

27. WANG, Y.; RAWLINGS, M.; GILBSON, D. T.; LABBE, D.; BERGERON, H.; BROUSSEAU, R.; LAU, P. C. Identification of a membrane protein and a truncated LysR-type regulator associated with the toluene degradation pathway in Pseudomonas putida F1. Mol. Gen. Genet., 1995, 246, p 570-579.

28. DELORENZO, V.; FERNANDEZ, S.; HERRERO, M.; JAKUBZIK, U.; TIMMIS, K. N. Engineering of alkyland haloaromatic-responsive gene expression with minitransposons containing regulated promoters of biodegradative pathways of Pseudomonas. Gene, 1993, 130, p 41-46.

29. FUCHSLIN, H. P.; RUEGG, I.; VAN DER MEER, J. R.; EGLI, T. Effect of integration of a GFP reporter gene on fitness of Ralstonia eutropha during growth with 2, 4dichlorophenoxyacetic acid. Environ. Microbiol., 2003, 5, p 878-887.

30. ABBY, A. M.; BEAUDETTE, L. A.; LEE, H.; TREVORS, J. T. Polychlorinated biphenyl (PCB) degradation and persistence of a gfp-marked Ralstonia eutropha $\mathrm{H} 850$ in PCB-contaminated soil. Appl. Microbiol. Biotechnol., 2003, 63, p 222-230.

31. WINTHER-LARSEN, H. C.; JOSEFSEN, K. D.; BRAUTASET, T.; VALLA, S. Parameters Affecting Gene Expression from the Pm Promoter in Gram-Negative Bacteria. Metab. Eng., 2000, 2, p 79-91.

32. KOHLER, S.; BACHMANN, T. T.; SCHMITT, J.; BELKIN, S.; SCHMID, R. D. Detection of 4-chlorobenzoate using immobilized recombinant Escherichia coli reporter strains. Sens. Actuator B., 2000, 70, p 139-144.

33. TRESSE, O.; ERRAMPALLI, D.; KOSTRZYNSKA, M.; LEUNG, K. T.; LEE, H.; TREVORS, J.T.; VAN ELSAS, J. D. Green fluorescent protein as a visual marker in a p-nitrophenol degrading Moraxella sp. FEMS Microbiol. Lett., 1998, 164, p 187-193. 
34. ERRAMPALLI, D.; OKAMURA, H.; LEE, H.; TREVORS, J. T.; VAN ELSAS, J. D. Green fluorescent protein as a marker to monitor survival of phenanthrenemineralising Pseudomonas sp. UG14Gr in creosotecontaminated soil. FEMS Microbiol. Ecol., 1998, 26, p 181-191.

35. ERRAMPALLI, D.; TRESS, O.; LEE, H.; TREVORS, J. T. Bacterial survival and mineralization of p-nitrophenol in soil by green fluorescent protein-marked Moraxella sp. G21 encapsulated cells. FEMS Microbiol. Ecol., 1999, 30, p 229-236.

36. DORN, E.; HELLWIG, M.; REINEKE, W.; KNACKMUSS, H. J. Isolation and characterization of a 3-chlorobenzoate degrading pseudomonad. Arch. Microbiol., 1974, 99, p 61-70.

\section{GFP PAGRINDO BIOSENSORIU TOBULINIMAS POLICHLORINTŲ BIFENILŲ (PCBS) BIOTINKAMUMUI IR BIODEGRADACIJAI NUSTATYTI}

\section{Liu, K. J. Germaine, D. Ryan and D. N. Dowling}

\section{Santrauka}

Sukonstruoti du ląsteliniai bioindikatoriai polichlorintų bifenilu in situ biodegradacijai nustatyti chromosominiu konstrukto mini-Tn5-Km ${ }^{\mathrm{F}}-\mathrm{Pm}:$ :gfp[mut3]- $\mathrm{T}^{0}-\mathrm{T}^{1}$ iterpimo į $P$. fluorescens būdu. Bandymai dirbtinèmis salygomis parodè, kad Pm aktyviklio išraiška priklauso nuo bioindikatoriaus augimo fazès ir cheminiu indikatoriu koncentracijos, taip pat nuo chlorintų benzenkarboksirūgščių derinių. Nustatyta tiesinè priklausomybė tarp fluorescentų intensyvumo ir indikatorių $\log _{10}$ koncentracijos. Vienas iš bioindikatorių (F113L::1180gfp) galèjo degraduoti PCBs iki tinkamų chlorobenzenkarboksirūgščiu deriniu ir indukuoti Gfp išraišką. Antrasis bioindikatorius (F113gfp), kuris negali degraduoti PCBs, parodo fluorescentiškumą ívykus indukcijai pagal chloro-benzenkarboksirūgščių derinius. Naudojant šiuos du bioindikatorius, PCB degradacija gali būti nustatyta tiek dirbtinėmis sąlygomis, tiek dirvožemyje.

Reikšminiai žodžiai: bioindikatoriai, Pseudomonas fluorescens F113, PCBs, rizosfera, šaknų kolonizacija.

\section{СОВЕРШЕНСТВОВАНИЕ БИОСЕНСОРОВ ОСНОВЫ GFР ДЛЯ ОПРЕДЕЛЕНИЯ БИОСООТВЕТСТВИЯ И БИОДЕГРАДАЦИИ ПОЛИХЛОРИРОВАННЫХ БИФЕНИЛОВ (РСВs)}

\section{Х. Лю, К. Й. Гермайне, В. Риан, Д. Н, Довлинг}

Р е $з$ ю м е

Сконструированы два клеточных биоиндикатора для выявления на участке биодеградации полихлорированных бифенилов путем хромосомного введения мини-Tn5-Kmr-Pm::gfp[mut3]-T0-T1 в P. fluorescen. Испытания в искусственных условиях показали, что выражение активатора Pm зависит от фазы роста биоиндикатора и концентрации химических индикаторов, а также от сочетаний хлорированных бензойных кислот. Наблюдалась линейная зависимость между интенсивностью флуоресцентов и концентрации $\log 10$ индикаторов. Один из индикаторов (F113L::1180gfp) мог способствовать деградации PCBs в сочетания соответствующих хлор-бензойных кислот и индуцировать выражение Gfp. Другой биоиндикатор (F113gfp), который не может способствовать деградации $\mathrm{PCB}$, показал флуоресцентность после индикации по сочетаниям хлор-бензойных кислот. С использованием этих индикаций деградация РСВ может наблюдаться лишь в искусственных условиях и лишь в почве.

Ключевые слова: биоиндикаторы, Pseudomonas fluorescens F113, PCBs, ризосфера, корневая колонизация.

Ms Xeumei LIU Bsc. Ms Xeumei Liu is a PhD student at IT Carlow under the supervision of Dr Dowling and Dr Ryan. Her research interests are in the development of biosensors and use of microarrays to study bacterial interactions with pollutants.

Mr Kieran GERMAINE Bsc. Mr Kieran Germaine BSc is a PhD student under the supervision of Dr Dowling and Dr Ryan. His research interests are in the area of endophytic and rhizospheric bacteria and their applications for bioremediation.

Dr David RYAN PhD. Dr Ryan is Head of Department of Science \& Health at IT Carlow. He has been a member of the Biotechnology and Molecular Environmental Sciences (BMES) research group at IT Carlow since 2000. Dr Ryans main research interests are the use and manipulation of microbial degradative and metal resistance mechanisms for improved bioremediation and enhanced phytoremediation of pollutant compounds. Currently, active projects in this area include the examination of metal resistant and xenobiotic degrading endophytic and rhizospheric bacteria for improved phytoremediation and phytocontainment, the molecular analysis of multi-efflux system(s) in the plant associated bacterium Xanthomonas and the examinataion of molecular resistance to tributyl-tin in exposed microbial strains and their bioremediation potential. Dr Ryan also supervises research for the design and development of an environmental DNA microarray for environmental genetic analysis as well as the construction and evaluation of microbial biosensors to detect both target contamination and degradation in a range of water/soil environments and conditions.

Dr David DOWLING PhD (corresponding author). Dr Dowling is Head of School of Science at IT Carlow and directs several research projects ranging from the development of biological treatments for the detoxification of waste chemicals to molecular methods for the detection of microorganisms in the environment. This research is funded by EU, National and Industrial sources. He has 20 years of experience in the area of biodegradation as well as plant-microbe interactions with 50 publications in refereed international scientific publications and over 130 conference papers, one patent application and has edited two books in the area of environmental biotechnology. He is a co-director of Microgen Biotechnologies, a campus unit dedicated to commercialisation of environmental biotechnology research at IT Carlow. He is a member of the EU Cost programme management committee (Cost 849) on Phytotechnolgies and has experience of cocoordinating EU projects. 